\title{
BIOCHEMICAL PARAMETERS IN COMMON VIRAL HEPATITIS
}

\author{
MD. ASHRAF-UZ-ZAMAN ${ }^{1}$, BILQUIS ARA BEGUM ${ }^{2}$, HUMAIRA BINTE ASAD ${ }^{3}$ SHAFIA SHARMIN \\ MOUTOSHI $^{4}$,MD. NASIRUDDIN ${ }^{5}$
}

\begin{abstract}
Viral hepatitis is the inflammation of the liver caused by hepatitis viruses. The most common causes of viral hepatitis are the five unrelated hepatotropic viruses Hepatitis A, Hepatitis B, Hepatitis $C$, Hepatitis D, and Hepatitis E. The aim of this study is to assess the biochemical parameters in viral hepatitis which varies with respect to the different types of viral hepatitis. Sex of the patient affected by Hepatitis A was almost similar in male and female, being 9 (45\%) and 11(55\%) in respectively. But in contrast, more than eighty per cent (85\%) Hepatitis-E affected population was male. Similar scenario was found in Hepatitis B And C infection (Male- 75\%,67\%, Female 25,35\%). Mean value with standard deviation ( $\pm S D)$ of serum bilirubin level was highest in Hepatitis E $(251 \pm 125.19 \mathrm{imol} / \mathrm{l})$. Value of serum ALT in hepatitis $E$ was found to be $1794 \mathrm{U} / \mathrm{l}$ (highest), hepatitis B $1362 \mathrm{U} / \mathrm{l}$ hepatitis C are 135.45 $U / L$, Serum aspartate aminotransferase (S.AST) is also raised in all types of vira hepatitis but more in Hepatitis E $(765 \mathrm{U} / \mathrm{l})$ and Hepatitis $B(430 \mathrm{U} / \mathrm{l})$. Serum Alkaline Phosphatase $(A L P)$ was raised significantly in Hepatitis $B(240 \mathrm{U} / \mathrm{l})$. The prothombin time was more altered in Hepatitis-E (22.7seconds) and Hepatitis-B(18.5 seconds). There was no significant alteration in serum protein level. So, it can be concluded that derangement of biochemical parameters in patients suffering from common types of viral hepatitis is more in HEV and $H B V$ and comparatively less in $H A V$ and $H C V$.
\end{abstract}

Keyword: Viral hepatitis, hepatitis A, hepatitis B, hepatitis $C$, hepatitis $D$, hepatitis $E$

\section{Introduction}

Viral hepatitis a major public health problem globally, Bangladesh is no exception. The hepatotropic viruses are the most important cause of viral hepatitis and can cause hepatocellular injury ranging from subclinical inflammation to hepatic failure, cirrhosis, cancer and death apart from other causes like excessive alcohol consumption, use of certain hepatotoxic drugs and other types of infectious and nutritional agents. Among the most important hepatotrophic viruses, hepatitis B virus (HBV), hepatitis $\mathrm{C}$ virus (HCV), hepatitis A virus (HAV) and hepatitis E virus (HEV) are commonly prevalent in the world and also in Bangladesh. Overall HAV accounts for $25 \%$ of clinically evident acute hepatitis worldwide, HBV has infected over 2 billion people worldwide with a carrier of 350 million. ${ }^{1-3} \mathrm{HEV}$ accounts for about $50 \%$ of cases of sporadic acute hepatitis in India and epidemics have also been reported in Indian subcontinent, subSaharan Africa and Mexico. ${ }^{4-6}$ The global prevalence varies from high $>8 \%$ in Africa, Asia, Western Pacific region, intermediate 2-7\% in South Eastern Europe and low $<2.5$ in Western Europe, North America and Australia. Prevalence of $\mathrm{HCV}$ is $1.8 \%$ in general population in USA, increasing up to $50 \%$ in

1. Assistant Professor, Department of Biochemistry, Ad-din Women's Medical College, Dhaka.

2. Professor \& Head of the Department of Biochemistry, Ad-din Women's Medical College, Dhaka.

3. Assistant Professor, Department of Biochemistry, Sir Salimullah Medical College,Mitford, Dhaka.

4. Assistant Professor, Department of Biochemistry, Holy Family Red Crescent Medical College, Dhaka.

5. Assistant Professor, Department of Biochemistry, NICVD, Dhaka.

Correspondence: Dr. Md. Ashraf-uz-zaman, Assistant Professor, Department of Biochemistry, Ad-din Women's Medical College, Dhaka 
unexplained cirrhosis and hepatocellular carcinoma (HCC) and is the most common cause of chronic liver disease. $^{4-6}$

The exact prevalence of hepatitis viruses varies from country to country and no exact data is available in Bangladesh. As the exact prevalence of hepatitis viruses are not known in Bangladesh, the present study was undertaken to asses the biochemical parameters in viral hepatitis which varies with respect to the different types of viral hepatitis. Fortunately, advances in serologic \& molecular testing now allow accurate identification of the viral causes of both acute $\&$ chronic hepatitis. ${ }^{7-10}$

Moreover, the biochemical parameters in viral hepatitis can assess the degree of liver damage. So by estimating the biochemical parameters we can assess the severity of different types of hepatitis viruses. The routes of spread of these viruses are different \& some of the viruses have got vaccines. So this study may help us to be aware of the most life threatening viruses.

\section{Materials and Methods}

This cross sectional study was carried out from January 2005 to December 2006 in Sir Salimullah Medical College and Hospital (SSMCH), Dhaka, Bangladesh. The study was conducted on a total number of 80 diagnosed viral hepatitis cases. All cases were selected by taking history \& laboratory investigations following the exclusion or inclusion criteria.
Inclusion criteria were : 5 years of age, clinically selected patient, confirmed by serological viral marker. Exclusion criteria were: Hepatitis due to other causes, patient having other chronic liver diseases such as cirrhosis, liver failure, liver cancer, rheumatoid arthritis, thyroid dysfunction

Study procedure: A total of 80 viral hepatitis patients with confirmed serological marker were included in this study from the outdoor and indoor patient department of Sir Salimullah Medical College Hospital. Each subject was explained verbally the nature \& purpose of the study in order to get a free $\&$ fair written consent. Data were collected in appropriate questionnaire and laboratory investigations were done from the collected blood samples. Serum was separated by centrifugation at 3000-4000 rpm for 3-5 minutes. Estimations were carried out as early as possible.

\section{Results}

Table I

Sex distribution in different study groups

\begin{tabular}{ccc}
\hline Group & Male & Female \\
\hline Hepatitis A $(\mathrm{n}=20)$ & $09(45 \%)$ & $11(55 \%)$ \\
Hepatitis B $(\mathrm{n}=20)$ & $15(75 \%)$ & $05(25 \%)$ \\
Hepatitis C $(\mathrm{n}=20)$ & $13(65 \%)$ & $07(35 \%)$ \\
Hepatitis E $(\mathrm{n}=20)$ & $17(85 \%)$ & $03(15 \%)$ \\
\hline
\end{tabular}

Table II

Biochemical parameters (S.Bilirubin, ALT, AST, ALP, Total protein, Albumin \& Prothrombin time) in different viral hepatitis.

\begin{tabular}{lcccc}
\hline Parameters & HAVN=20 & HBVN=20 & HCVN=20 & HEVN=20 \\
\hline S. Bilirubin(Mean \pm SD) $\mu \mathrm{mol} / \mathrm{l}$ & $226 \pm 110.37$ & $247 \pm 169.64$ & $38 \pm 11.84$ & $251 \pm 125.19$ \\
S. ALT(Mean $\pm \mathrm{SD}) \mathrm{U} / \mathrm{l}$ & $813 \pm 301.9$ & $1362 \pm 1256.16$ & $135.45 \pm 129.57$ & $1794 \pm 1115.23$ \\
S. AST(Mean $\pm \mathrm{SD}) \mathrm{U} / \mathrm{l}$ & $164 \pm 94.29$ & $430 \pm 415.66$ & $107.5 \pm 105.02$ & $765 \pm 734$ \\
S. ALP(Mean $\pm \mathrm{SD}) \mathrm{U} / \mathrm{l}$ & $98 \pm 63.56$ & $240 \pm 190.68$ & $92 \pm 32.69$ & $172 \pm 88.94$ \\
S. total protein(Mean $\pm \mathrm{SD}) \mathrm{g} / \mathrm{dL}$ & $6.95 \pm .36$ & $6.94 \pm .37$ & $7.3 \pm .55$ & $6.8 \pm .47$ \\
S. Albumin(Mean $\pm \mathrm{SD}) \mathrm{g} / \mathrm{dL}$ & $3.7 \pm .56$ & $3.8 \pm .73$ & $3.16 \pm .52$ & $3.6 \pm .49$ \\
Prothrombin time in sec. $($ Mean $\pm \mathrm{SD})$ & $15.7 \pm 2.66$ & $18.4 \pm 7.14$ & $15.9 \pm 3.35$ & $22.7 \pm 13.55$ \\
\hline
\end{tabular}




\section{Discussion}

The present study was carried out to asses the severity of viral hepatitis in respect to different biochemical parameters in common viral hepatitis patients. Eighty diagnosed patients of different viral hepatitis- Hepatitis A, Hepatitis B, Hepatitis C and Hepatitis E were selected for study. Each group consisted of 20 patients. Biochemical parameters of all patients were studied. ${ }^{11}$

Regarding serum bilirubin higher level was observed in all types of viral hepatitis but highest level was observed in Hepatitis E, then Hepatitis B \& Hepatitis A. Lowest value was observed in Hepatitis C. This pattern of variations of serum bilirubin of viral hepatitis is consistent with the study of Bhupinder 2004 , but they found relatively lower level of serum bilirubin than that of our study, may be due to small sample size. ${ }^{11}$

Serum level of alanine aminotransferase (S.ALT) was observed \& found to be high in all patients of our study but highest in case of Hepatitis E followed by Hepatitis B and Hepatitis A, lowest in case of Hepatitis C. Higher level of S.ALT, similar to present study was found in another group of study. ${ }^{12}$

Serum AST was found to be increased in all types of viral hepatitis although the increase was lesser than that of serum ALT. The increase was highest in Hepatitis E followed by Hepatitis B and Hepatitis A, lowest in Hepatitis C.

Serum alkaline phosphate (ALP) was increased in Hepatitis B and was within normal limit in other groups. Highest in Hepatitis B is followed by Hepatitis E \& Hepatitis A, lowest in case of Hepatitis C. Similar results was found in other studies. ${ }^{13}$

Serum total protein values were not significantly altered in cases of all four types of Hepatitis. As most of the cases were in acute stage of the disease, so these unaltered values are expected. The increase of serum total protein in HCV might be due to the fact that HCV proteins usually come to hospital in chronic stage.

Serum albumin levels were found almost within normal range in most of the cases. Highest in Hepatitis B, followed by HAV \& HEV, lowest in cases pf Hepatitis C. Albumin globulin ratio was observed \& found highest in cases of HBV followed by HAV \& $\mathrm{HEV}$, lowest in HCV. Prothrombin Time (PT) is a sensitive parameter of liver function and signifies both acute and chronic infection. It was found to be high in all the cases of viral hepatitis. Highest in HEV followed by HBV \& HCV, lowest in HAV. These values are similar in comparison with other studies where prothrombin time (PT) was found to be relatively high in all types of viral hepatitis. ${ }^{14}$

\section{Conclusion}

Serum bilirubin was raised in all the types of viral hepatitis. Among them subjects with HEV showed marked raised level. On the other hand subject with HCV had the lowest level of serum bilirubin. Serum ALT and AST were also raised in all groups but were highest in subjects with HEV and the lowest level was observed in subjects with HCV. The reason behind the abnormal level can not be explored conclusively but within this limitation our study showed comparatively higher ALP value in subjects with HBV and then HEV and apparently no difference in HAV \& HCV groups. Serum total protein, albumin, globulin and albumin-globulin ratio showed equivocal status. Prothrombin time was raised from the normal in all the groups. Highest increase was observed in HEV groups than HBV, HCV and HAV successively.

Considering the above statements it can be concluded that derangement of liver function in patients suffering from common types of viral hepatitis is more in HEV and HBV and comparatively less in HAV and HCV on the basis of evaluation of different biochemical parameters.

\section{References}

1. Mohler-Kuo M, Steffen R, Bopp M, Jacobs RJ, Mutsch M. Prevalence of hepatitis A virus risk factors in a very low endemic country, Switzerland. Vaccine 2007;25: 8718-25.

2. Minuk GY, Sun A, Sun DF, Uhanova J, Nicolle LE, Larke B, Giulivi A. Serological evidence of hepatitis $E$ virus infection in an indigenous North American population. Can J Gastroenterol 2007; 21: 439-45.

3. Bayram A, Eksi F, Mehli M, Sozen E. Prevalence of hepatitis $\mathrm{E}$ virus antibodies in patients with chronic hepatitis B and chronic hepatitis C. Intervirology 2007; 50: 281-86.

4. Spada E, Abbate I, Sicurezza E, Mariano A, Parla V, Rinnone S, Cuccia M, Capobianchi MR, Mele A. Molecular epidemiology of a hepatitis $\mathrm{C}$ virus outbreak in a hemodialysis unit in Italy. J Med Virol 2008; 80: 216-17. 
5. Nahar D, Biswas J, Nahar A, Haque KMG, Islam A, Mannan MA. Hepatitis B virus infections in patients with chronic liver disease. Bangladesh Med Assoc J 2001; 30: 43-45.

6. Haque MM, Mamun SA, Khan RM, Hassan KM, Salam A. Hepatitis B virus infection in heterosexual men having multiple sex partners. Bangladesh Med Assoc J. 2004; 33: 78-85.

7. Khan WI, Sultana R, Rahman M, Akhter H, Haq JA, Ali L, Mohsin MA, Khan AKA. Viral hepatitis: Recent experiences from serological studies in Bangladesh. Asian Pacific J Allergy Immunol 2000; 18: 99-103.

8. Shapiro CN, Mangolis HS. Worldwide epidemiology of hepatitis A virus infection. J Hepatol 1993; 18 (Suppl 2): S11-14.

9. Mujeeb SA, Shaikh MA, Kehar SI. Prevalence of HB infection in hemodialysis patients. J Pak Med Assoc $1994 ; 44: 226$.
10. Saab S, Martin P. Tests for acute and chronic viral hepatitis: finding your way through the alphabet soup of infection and super infection. Journal of Postgrad Med 2000; 107( 2): 123-30.

11. Bhupinder S, Anand M. Assessment of correlation between serum titers of hepatitis $\mathrm{C}$ virus and severity of liver disease. World J Gastroentrol 2005; 15(10): 2409-2411.

12. Hossain Z, Das B, Hussain SA 2006. Virological cause of hepatitis A virus, as determined by real time RT- PCR: correlation with biochemical immunological and genotype profiles. World J Gastroenterol 2006; 29: 4683-8.

13. Sainokami SA, Ishikewa K. Influence of hepatitis A virus on disease severity and its relationship with clinical manifestation in patients with hepatitis A. Journal of Gastroenterol Hepatol 2005;8:165-75.

14. Androene P, Biselli M, Gramanzi 2002. Efficacy of lamivudin therapy for advance liver disease in patients with pre-core mutant hepatitis B virus infection: awaiting liver transplantation'. Transplantation 2002; 74(8):1119-24. 